\title{
Price Spillover and Dynamic Correlation in the Shanghai A- and B-Share Stock Markets: Evidence from the B-Share's Opening to Chinese Citizens
}

\author{
Jung-Lieh $\mathrm{Hsiao}^{1} \&$ Teng-Tsai Tu${ }^{1}$ \\ ${ }^{1}$ Graduate Institute of International Business, National Taipei University, Taiwan \\ Correspondence: Jung-Lieh Hsiao, Graduate Institute of International Business, National Taipei University, No. \\ 151, University Rd., SanShia District, New Taipei, 23741, Taiwan, ROC. Tel: 886-2-8674-1111 ext 66877. \\ E-mail: jhsiao@mail.ntpu.edu.tw
}

Received: December 17, 2012

Accepted: April 19, $2013 \quad$ Online Published: May 17, 2013

doi:10.5539/ibr.v6n6p115

URL: http://dx.doi.org/10.5539/ibr.v6n6p115

\begin{abstract}
This study adopts a bivariate EGARCH model, augmented with correlation index function, to examine the bilateral relationships between the Shanghai A- and B-share stock markets. Daily closing A- and B- share index prices, as well as S\&P 500 index prices are used and they span from January 2, 1997 through December 30, 2005, a total of 2170 observations. A mean spillover from the B- to A-share market was found in the post-opening period and not the other way around. In addition, the US market plays an important role of information transmission to the B-share market. Moreover, a change in responsiveness of cross-market correlation to information arrivals was also detected after B-share's opening to Chinese citizens.
\end{abstract}

Keywords: bivariate EGARCH model, correlation index function, mean spillover, B-share's opening

\section{Introduction}

Two major regulatory policy changes were undertaken to integrate the previously segmented A- and B- shares markets in China. Firstly, the China authority, through the China Securities Regulatory Commission (CSRC), announced on February 19, 2001 that domestic investors were eligible to trade B-shares, which was previously only tradable by foreigners. Secondly, the CSRC partially opened the A-share market to foreign investors via the scheme of Qualified Foreign Institutional Investors (QFIIs), allowing them to invest in China's A-share market through a pre-approved mechanism. The first policy change is viewed as backward (or reverse) stock market liberalization, while the second policy change is a forward (or normal) market liberalization process. These two policy changes are expected to hasten the development of Chinese stock markets. Intuitively, two such policy changes may induce more interactions between A- and B-share stock markets than before. Thus, this study examines the effectiveness of regulatory policy changes on the bilateral relationships between Shanghai A- and B-share stock markets. More specifically, it would be interesting to investigating whether or not stock market liberalization has effect on the interactions between A-share and B-share index returns.

The opening of the B-share market to domestic investors was designed to improve market activity and quality. For instance, the B-share trading volume and liquidity were much higher immediately after the opening. In addition, transaction costs (bid-ask spreads) and B-share price discounts were lower than before. According to Lu, Wang, Chen, and Chong (2007), the policy goal of increasing liquidity in the B-share market has been achieved to a large extent, and its opening also led to a drop in the A-share price premium. Thus, opening B-shares may increase information transparency because domestic investors, along with foreign investors, trade more B-shares. The improvement in B-share market activity and quality, associated with the deregulation of restriction on arbitrage between A- and B-share markets, should reduce information asymmetry to some extent and thus put A- and B-shares on the road to convergence. Specifically, the main focus of our research will be on the effects of market liberalization on mean spillover, volatility spillover, and cross-market correlation between A- and B-share markets. Before going further, one more thing worth of mention is the impact of global market information, represented by the US S\&P500 index in this study, on the A-share or the B-share stock markets. That is, it would be interesting to note which market could be influenced by the US factor as well.

Coupled with World Trade Organization (WTO) entry commitments, China's capital market will unavoidably 
encounter international competition. However, prior to forward market liberalization, the development of the B-share market can be viewed as a testing ground for further opening China's capital market to foreign countries. The initial purpose of building the B-share market was to attract overseas investment and thus more foreign funds. Afterwards, China opened more and more financing channels, such as N-shares, L-shares, $\mathrm{H}$-shares and red-chip shares. Therefore, the role played by B-share had gradually waned over time. Accordingly, to reposition the B-share market to support the development of the national economy, the China CSRC announced on February 19, 2001 that domestic residents would be allowed to trade B-shares from the end of February 2001 onwards. Another related scheme to open the domestic A-share market to foreign capital was revealed when the China authority announced that QFIIs could invest in A-share stocks from December 2, 2002 onwards. These new policies aim to broaden the investment base and in turn, bring more trading and more quality-oriented information into the A- and B-share markets. Opening the B-share market and implementing QFIIs may reinforce spillover and increase correlation. However, the QFII scheme may take longer than expected to exert its influence on stock market behavior. China's QFII initiative imposes some limitations that decrease the speed of foreign funds flowing into China's stock markets for the first few years. In addition, the statistically possible structural break dates fall on March 7, 12, and 20, 2001 under different model types, which are close to the date of announcement of opening B-shares to trade, according to Gregory and Hansen's (1996) method.

The price spillover and cross-market correlation between the Shanghai A- and B-share stock markets are important for financial decisions including strategy of asset allocation, pricing of derivatives and international portfolio. For example, asset allocation strategy would change of necessity if cross-market correlation increases. More trading information shared by investors in both the A- and B-share markets, which in turn would influence the pricing and assessment of derivative securities, especially since their payoff depends on more than one underlying asset price (Muthuswamy, Sarkar, \& Terry, 2001). Thus, further research on the effect of opening B-shares seems promising, and more price behaviors of Chinese stock markets are worth studying.

The rest of this paper is organized as follows. The following section reviews related research. Section 3 discusses the econometric models constructed for investigating the behaviors of price spillover and time-varying cross-market correlation. Section 4 provides some details about the sample data. Section 5 presents and analyzes empirical results, while Section 6 draws conclusions.

\section{Literature Review}

The free flow of capital, facilitated by stock market liberalization or increased market deregulation, and the improvement in electronic communication across national markets, has led to markets becoming more interdependent (Roll, 1989; Jeon \& Chiang, 1991). An increasing amount of empirical evidence reveals a simultaneous relationship between stock market volatilities and cross correlations. For example, Eun and Shim (1989) found that innovations in the US stock market were rapidly transmitted to the rest of the world, although innovations in other national markets did not have much effect on the US market. Hamao, Masulis, and $\mathrm{Ng}$ (1990), Koutmos and Booth (1995), and Susmel and Engle (1994) focused on spillovers across New York, London, and Tokyo. Theodossiou and Lee (1993) investigated spillovers across the US, Japan, Canada, and Germany. Karolyi (1995) tested for spillovers between Canada and the US and Kanas (1998) reported volatility transmissions between stock markets in Paris, London, and Frankfurt. These studies clearly identify spillover effects between national stock markets, and they may be analogically conducted between intra-country markets such as A- and B-share stock markets in China.

Jayasuriya (2005) investigated the effects of stock market liberalization on volatility in the presence of favorable market characteristics and institutions. Furthermore, the effect of the QFII initiative on the change in stock market volatility contributes to a change in correlation. This delineation finds support in the recent works of Ramchand and Susmel (1998), Domanski and Kremer (2000), and Jochum (2001), who maintained that increase in correlation be temporary and coincide with an increase in volatility.

Ramchand and Susmel (1998) showed that correlations between the US and other world markets were higher when the U.S. market was in a high variance state than in a low regime. King, Sentana, and Wadhwani (1994) used monthly returns for the period January 1970 through October 1988 to find time-varying covariance. Using the Chow test for the years 1972, 1980, and 1987, Koch and Koch (1991) found higher correlations in more recent years. Longin and Solink (1995) used a bivariate GARCH model to find that correlations between markets were higher when markets experienced high volatility. Karolyi and Stulz (1996) constructed an index of American Depositary Receipt (ADR) and found that covariances between this index and American returns were higher when national index returns were high. Using a logistic exponential GARCH model, Darbar and Deb (2002) found that market information in a market affected subsequent cross-market correlations between domestic asset markets. Using an asymmetric dynamic conditional correlation GARCH model, Gupta and 
Donleavy (2009) found that there were still potential benefits for Australian investors who diversified into international emerging markets. Gupta and Mollik (2008) examined the changing correlations between Australian and emerging markets. In some cases, the ratio of emerging market volatility to that of the Australian market influenced the changes in correlations. In addition, the relationship between the correlations and volatilities was stronger in some country pairs.

As far as market integration is concerned, Narayan and Smyth (2005) utilized Gregory and Hansen's (1996) co-integration method to find that the New Zealand and United States stock markets were co-integrated, but the New Zealand stock market was not co-integrated with the other stock markets in study. Lu, Wang, Chen, and Chong (2007) found that the opening of B-shares increased market efficiency and reduced the price differential between A- and B-shares in China. Finally, Sun, Tong, and Yan (2009) showed that the B-share market has displayed higher turnover, lower volatility and bid-ask spread, and more liquidity since its opening. In other words, the A- and B-share markets tend to converge over time. Qiao, Chiang, and Wong (2008) found that allowing domestic investors to purchase B-shares accelerated the market integration process of the A-share market with the B-share and Hong Kong markets. Hung (2009) investigated the effect of opening the B-share market on market efficiency, and showed that the weak-form EMH gains some support for both Shanghai A- and B-share markets in the post-opening B-share period. Cajueiro, Gogas, and Tabak (2009) assessed whether the financial market liberalization introduced in the beginning in 1990s has changed the degree of market development. Their study suggests that changes in financial market liberalization have had an important positive effect on market efficiency. Jaleel and Samarakoon (2009) examined the influence of Sri Lankan market liberalization on volatility and found that both conditional and unconditional volatility measures were the highest in the liberalization period. Lin and Swanson (2008) found that China's market reform is somewhat ineffective, and its segmented markets continue to provide foreign investors with the benefits of international diversification.

While the literature review above focuses on information transmission between national markets and contemporaneous correlation, this study focuses on bilateral relationships between Shanghai A- and B-share stock markets, and especially the effect of regulatory policy change on spillover and domestic cross-market correlation. Ross (1989) declared that volatility is directly related to the rate of flow of information to the market, in which information can be used to link stock markets. Thus, we define the US market volatility, represented by squared index returns, as a proxy variable of international information, and the absolute A- and B-share market returns as a proxy variable for domestic market information arrival (Covrig \& Ng, 2004). These two types of information transmission will be considered and tested in the upcoming empirical model.

\section{Research Methodologies}

The major research methodologies include two subsections: unit-root and cointegration tests; bivariate EGARCH model augmented with correlation index function.

\subsection{Unit-Root and Cointegration Tests}

The traditional augmented Dickey-Fuller (ADF) tests are generally used to test for stationarity in financial time series. However, according to Zivot and Andrews (1992), if the sample data contains a significant event, it must be taken into account in unit root testing. The Zivot and Andrews test makes it possible to establish the unit root properties of the data in the presence of one structural break. Thus, the suggested equations are as follows:

$$
\begin{gathered}
P_{t}=\alpha_{A}+\beta_{A} t+\emptyset_{A} P_{t-1}+\gamma_{A} D U_{t}(\hat{\lambda})+\sum_{i=1}^{k} \theta_{A i} \Delta P_{t-i}+e_{A t} \\
P_{t}=\alpha_{B}+\beta_{B} t+\emptyset_{B} P_{t-1}+\gamma_{B} D T_{t}(\hat{\lambda})+\sum_{i=1}^{k} \theta_{B i} \Delta P_{t-i}+e_{B t} \\
P_{t}=\alpha_{C}+\beta_{C} t+\emptyset_{C} P_{t-1}+\gamma_{C} D U_{t}(\hat{\lambda})+\varphi_{C} D T_{t}(\hat{\lambda})+\sum_{i=1}^{k} \theta_{C i} \Delta P_{t-i}+e_{C t}
\end{gathered}
$$

where $P_{t}$ is the natural $\log$ of market index, $D U_{t}(\hat{\lambda})=1$ if $t>T \hat{\lambda}, 0$ otherwise, and $\hat{\lambda}$ is equal to $T_{B} / T$; $D T_{t}(\hat{\lambda})=t-T \hat{\lambda}$ if $t>T \hat{\lambda}, 0$ otherwise. The "hats" on the $\lambda$ parameters in (1) through (3) emphasize that these parameters correspond to estimated values of the break fraction. $T$ is the sample size and $T_{B}$ is the point at which structural break occurs. The next step is to determine the cointegrating property in the presence of a structural break. Using Gregory and Hansen's (1996) method, we estimate the following equations:

$$
\begin{gathered}
P_{B, t}=\alpha+\varphi D U_{t}\left(\hat{\lambda}_{G H}\right)+\eta_{1} P_{A, t}+\varpi_{1, t} \\
P_{B, t}=\alpha+\beta t+\varphi D U_{t}\left(\hat{\lambda}_{G H}\right)+\eta_{1} P_{A, t}+\varpi_{2, t} \\
P_{B, t}=\alpha+\varphi D U_{t}\left(\hat{\lambda}_{G H}\right)+\eta_{1} P_{A, t}+\eta_{2} D U_{t}\left(\hat{\lambda}_{G H}\right) P_{A, t}+\varpi_{3, t}
\end{gathered}
$$

In these equations, $\alpha$ represents the intercept before the shift, $\beta$ stands for the coefficient of time trend, and $\varphi$ represents the change in the intercept at the time of the shift; $\eta_{1}$ denotes the cointegrating coefficients and $\eta_{2}$ 
is the change in the slope. $D U_{t}\left(\hat{\lambda}_{G H}\right)$ is a dummy variable that is set to one after the change point, and zero otherwise. These three models are called a 'constant model,' which includes an intercept and a level shift dummy, a 'trend model,' which includes an intercept, trend, and a level shift dummy, and a 'full break model,' which includes no trend, but dummies for the intercept and the slopes, respectively.

\subsection{Bivariate EGARCH Model}

This study employs the bivariate EGARCH model developed by Nelson (1991) and extended by Darbar and Deb (2002) to investigate the possible interactions within the conditional mean and conditional variance of returns of the A- and B-share stock markets in Shanghai. This EGARCH model considers a dynamic correlation structure (Note 1). Numerous papers have used the EGARCH model to describe the asymmetric effects and volatility clustering in the equity and futures markets: Bae and Karolyi (1994), Booth, Martikainen, and Tse (1997), Tse (1998), Bhar (2001), Darbar and Deb (2002), Skintzi and Refenes (2006), and many others.

The advantage of applying the EGARCH model is that it captures the leverage effect found in finance literature and avoids non-negativity restrictions on the values of the GARCH parameters to be estimated. Based on the Likelihood Ratio (LR) tests of alternative specifications, the empirical study will be executed by using a bivariate EGARCH $(1,1)$ with MA (1) model.

In addition to the investigation on price spillovers and cross-market correlation, this paper is also to test whether the arrival of new market information at time $t-1$ significantly affects the correlation between A- and B-share markets. To achieve this purpose, the bivariate EGARCH model is augmented with a dynamic correlation structure where variables proxied for market information arrival are added in.

To illustrate, consider A-share and B-share, and let market $1=\mathrm{A}$-share and market 2 = B-share. The resulting bivariate EGARCH $(1,1)$ with MA (1) model is as follows (Note 2):

$$
\begin{gathered}
R_{1, t}=\mu_{1}+\varepsilon_{1, t}+\beta_{1} \varepsilon_{1, t-1}+\left(\gamma_{10}+\gamma_{10}^{*} D_{o p, t}\right) \varepsilon_{2, t-1}+\left(\phi_{10}+\phi_{10}^{*} D_{o p, t}\right) R_{u s, t-1} \\
R_{2, t}=\mu_{2}+\varepsilon_{2, t}+\beta_{2} \varepsilon_{2, t-1}+\left(\gamma_{20}+\gamma_{20}^{*} D_{o p, t}\right) \varepsilon_{1, t-1}+\left(\phi_{20}+\phi_{20}^{*} D_{o p, t}\right) R_{u s, t-1} \\
\varepsilon_{t}=\left[\begin{array}{c}
\varepsilon_{1, t} \\
\varepsilon_{2, t}
\end{array}\right], \quad \begin{array}{c}
\varepsilon_{t} \mid \Omega_{\mathrm{t}-1} \sim N\left(0, H_{t}\right), \text { with the conditional covariance matrix: } \\
\ln \left(\sigma_{1, t}^{2}\right)=a_{1}+b_{1} \ln \left(\sigma_{1, t-1}^{2}\right)+\delta_{11} G_{1, t-1}+\left(\delta_{12}+\delta_{12}^{*} D_{o p, t}\right) G_{2, t-1}+\left(\theta_{11}+\theta_{11}^{*} D_{o p, t-1}\right) \ln \left(1+R_{u s, t-1}^{2}\right) \\
\ln \left(\sigma_{2, t}^{2}\right)=a_{2}+b_{2} \ln \left(\sigma_{2, t-1}^{2}\right)+\delta_{21} G_{2, t-1}+\left(\delta_{22}+\delta_{22}^{*} D_{o p, t}\right) G_{2, t-1}+\left(\theta_{21}+\theta_{21}^{*} D_{o p, t-1}\right) \ln \left(1+R_{u s, t-1}^{2}\right) \\
G_{i t}=\left(\left|z_{i t}\right|-E\left|z_{i t}\right|+w_{i} z_{i t}\right), z_{i t}=\varepsilon_{i, t} / \sigma_{i, t}, i=1 \text { or } 2
\end{array}
\end{gathered}
$$

where $E\left|z_{i t}\right|=(2 / \pi)^{1 / 2}$.

Due to the intensive cross-correlation between $\varepsilon_{1 t}$ and $\varepsilon_{2 t}$, which may lead to misleading estimates, we follow Bekaert, Harvey, and Ng's (2005) method of considering only the information from the Shanghai B-share market $\left(e_{2 t}\right)$, and not that contained in the Shanghai A-share market, in the first conditional mean equation. That is, the new orthogonalized residuals were obtained from the regression: $\varepsilon_{2 t}=k_{0}+k_{1} \varepsilon_{1 t}+e_{2 t}$. The same procedure is also applied to the second conditional mean equation. Except for the covariance equation, the cross-market innovations are substituted into the previous conditional mean equations:

$$
\begin{aligned}
& R_{1, t}=\mu_{1}+\varepsilon_{1, t}+\beta_{1} \varepsilon_{1, t-1}+\left(\gamma_{10}+\gamma_{10}^{*} D_{o p, t}\right) e_{2, t-1}+\left(\phi_{10}+\phi_{10}^{*} D_{o p, t}\right) R_{u s, t-1} \\
& R_{2, t}=\mu_{2}+\varepsilon_{2, t}+\beta_{2} \varepsilon_{2, t-1}+\left(\gamma_{20}+\gamma_{20}^{*} D_{o p, t}\right) e_{1, t-1}+\left(\phi_{20}+\phi_{20}^{*} D_{o p, t}\right) R_{u s, t-1}
\end{aligned}
$$

The conditional mean equations are specified as Eq. (10) and the parameters, $\gamma_{10}$ and $\gamma_{20}$, measure the effect of the B-share stock returns on the returns of A-share market and the effect of the A-share stock returns on the returns of B-share market, respectively. Also, $\phi_{10}$ and $\phi_{20}$ measure the effect of the US stock market returns on the returns of A-share market and B-share markets, respectively. In a similar sense, parameters, $\gamma_{10}^{*}, \gamma_{20}^{*}, \emptyset_{10}^{*}$ and $\emptyset_{20}^{*}$, detect the effects of B-share opening on both A- and B-share markets. The dummy variable, $D_{o p, t}$, corresponds to one when observations fall on and after the structural break date, and zero otherwise. In addition, Equation (10) includes the moving average term, $\varepsilon_{t-1}$, to capture the effects of non-synchronous trading (Susmel and Engle, 1994). This effect seems to frequently occur in emerging stock markets.

In the conditional variance equations $(8)$, the coefficient, $\delta_{12}\left(\delta_{22}\right)$, measures the volatility spillover from the B-share (A-share) market to A-share (B-share) markets. The volatility spillover coefficients, $\theta_{11}$ and $\theta_{21}$, measure the effects of the US squared market returns on the A- and B-share markets, respectively. Similarly, parameters, $\delta_{12}^{*}, \delta_{22}^{*}, \theta_{11}^{*}$ and $\theta_{12}^{*}$, detect the effects of B-share opening on both market's volatilities of returns. 
The function, $G_{i t}$, defined by Eq. (9), allows past standardized innovations to influence the conditional variance asymmetrically. The first two terms, $\left|z_{i t}\right|-E\left|z_{i t}\right|$, measure the magnitude effects, whereas, the third term, $w_{i} z_{i t}$, measures the sign effect. The sign effect may enhance or partially offset the magnitude effect depending on the sign of coefficients. For example, if $w_{1}\left(w_{2}\right)$ is negative and $\delta_{11}\left(\delta_{21}\right)$ is positive, a negative innovation in the previous period will be followed by higher conditional volatility than positive innovation. This response is called the leverage effect, whereby market declines increase the aggregate debt to equity ratio and, thus, increase volatility (Black, 1976; Christie, 1982; Nelson, 1991, among others). Furthermore, if $w_{2}\left(w_{1}\right)$ is significantly negative and $\delta_{12}\left(\delta_{22}\right)$ is positive, this response is called cross-market leverage effect.

Now, take the first derivative with respect to $z_{i t}$, that is,

$$
\frac{\partial G_{i t}}{\partial z_{i t}}=1+w_{i}, z_{i t}>0, \text { or } \frac{\partial G_{i t}}{\partial z_{i t}}=1+w_{i}, z_{i t}>0
$$

and the relative asymmetry may be measured by the quantity:

$$
\left|-1+w_{i}\right| /\left(1+w_{i}\right)
$$

If this quantity is greater than, equal to, or less than one it means negative asymmetry, symmetry, and positive asymmetry, respectively.

For the conditional volatility process to be stationary, $\left|b_{i}\right|<1$ is required. The persistence of volatility is measured by the half-life $(H L)$ :

$$
H L(\text { half life })=\frac{\ln (0.5)}{\ln \left(b_{i}\right)}, i=1,2
$$

As mentioned previously, the policy of opening B-shares to trade was an attempt to enhance the B-share market's trading activity. Market information arrivals may affect the conditional correlations between the A- and B-share markets. Consequently, time-variability of conditional correlations should be considered. The resulting volatility model specification is structured as follows:

$$
\begin{gathered}
\sigma_{12, t}=\rho_{12, t} \sigma_{1, t} \sigma_{2, t} \\
\rho_{12, t}=2\left(\frac{1}{1+\exp \left(-\xi_{12, t}\right)}\right)-1 \\
\xi_{12, t}=\left(c_{0}+c_{0}^{*} D_{o p, t}\right)+c_{1} z_{1, t-1} z_{2, t-1}+c_{2} \xi_{12, t-1}+\left(c_{3}+c_{3}^{*} D_{o p, t}\right)\left|R_{1, t-1}\right|+\left(c_{4}+c_{4}^{*} D_{o p, t}\right)\left|R_{2, t-1}\right|
\end{gathered}
$$

To ensure that the conditional correlation, $\rho_{12, t}$, falls within the range $[-1,1]$, an index function $\xi_{12, t} \in(-\infty, \infty)$ was used following a methodology developed by Darbar and Deb (2002) (Note 3). Equation (16) specifies a correlation index function that depends on the cross-products of the standardized innovations and the past values of the index function. The conditional correlation is a logistic transformation of the index function, as Equation (15) shows.

King, Sentana and Wadhwani (1994) obtained the contemporaneous relationship between cross-market correlation and informational arrivals by using intertemporal asset pricing theory. Darbar and Deb (2002) extended their framework to demonstrate how cross-market correlation at time $t$ is affected by information arrivals at time t-1. Specifically, Darbar and Deb (2002) considered two types of information, common and market-specific, that can be positively or negatively related to cross-market correlation.

Previous studies provide several measures for market information flows. Ross (1989) showed that return variances are directly related to the rate of flow of information to the market. Lamoureux and Lastrapes (1990) modeled the relationship between price volatility and market information arrivals. Covrig and $\mathrm{Ng}$ (2004) used the absolute value of daily return as a proxy for information flow to the market. This empirical study follows the method of Covrig and $\mathrm{Ng}$ (2004). Note that the measure of market information arrivals does not distinguish between private and public information (Covrig and $\mathrm{Ng}, 2004$ ) or between common and market-specific information, as noted by Darbar and Deb (2002). Thus, the parameters $\mathrm{c}_{0}^{*}, \mathrm{c}_{3}^{*}$, and $\mathrm{c}_{4}^{*}$ in Equation (16) can capture the effect of B-share opening on cross-market correlation.

Given a sample of $T$ observations, this study estimates the parameters of the bivariate EGARCH model by maximizing the following log-likelihood function:

$$
L(\Theta)=-T \ln (2 \pi)-\frac{1}{2} \sum_{t=1}^{T}\left(\ln \left|H_{t}\right|+\varepsilon_{t}^{\prime} H_{t}^{-1} \varepsilon_{t}\right.
$$

where $\Theta$ is the parameter vector of the model to be estimated and $\varepsilon_{t}$ is the $2 \times 1$ vector of residuals at time $t$, with its corresponding $2 \times 2$ conditional variance-covariance matrix $H_{t}$. The BFGS algorithm is then used to obtain the final estimate of the variance-covariance matrix with corresponding standard errors. Robust standard 
errors were calculated using the method given by Bollerslev and Wooldridge (1992) to consider possible violation of the assumption of normality for the conditional errors.

\section{Data and Descriptive Statistics}

Daily closing index prices for A- and B-share stock markets in the Shanghai Securities Exchange were collected from Taiwan Economic Journal (TEJ) for the period from January 2, 1997 through December 30, 2005, for a total of 2170 observations. Following Lu et al. (2007) and Sun, Tong, and Yan (2009), this study uses daily index prices for both Shanghai A- and B-share markets along with daily S\&P 500 index prices to represent the US stock market. Continuously compounded returns (denoted by $\left.R_{t}=\left(\ln \left(P_{t}\right)-\ln \left(P_{t-1}\right)\right) * 100\right)$ are all measured in terms of Chinese currency and calculated as the difference in natural logarithms of the closing index (denoted by $P_{t}$ ) for two consecutive trading days.

Given the continuous economic development and reform in China, the opening of B-shares should keep foreign funds flowing into Chinese stock markets, with domestic funds overwhelmingly flowing into the B-share stock markets. The market reaction was electric, as thousands of Chinese investors poured into the B-share market. The B-share price index rose sharply from 84.608 to 127.804 for nine continuous trading days from February 28 , 2001 through March 12, 2001, which is equal to a $51.05 \%$ index price change.

Both inward and outward stock market liberalization should produce more intensive interactions between A- and B-share markets. From Table 1, it shows that the trading volume or trading value of B-shares in 2001 exhibited a big jump compared to previous and subsequent years. This obvious change indicates that the opening of the B-share market improved the market trading activity for a while. The B-share trading volume increased from 72.13 million in 1999 to 390.27 million in 2001, showing a growth of more than $400 \%$. In the same period, the A-share market saw a negative growth of $3.93 \%$. This observation indicates that the opening of B-share benefited the B-share market development without adversely affecting the A-share market, as Figure 1 shows.

Table 1. Comparison of A- and B-shares in the Shanghai Stock Market

\begin{tabular}{|c|c|c|c|c|c|c|c|c|}
\hline Year & $\begin{array}{l}\text { A-share } \\
\text { return }(\%)\end{array}$ & $\begin{array}{l}\text { Trading } \\
\text { volume }\end{array}$ & $\begin{array}{l}\text { Trading } \\
\text { value }\end{array}$ & $\begin{array}{l}\text { Turnover } \\
\text { Rate (\%) }\end{array}$ & $\begin{array}{l}\text { B-share } \\
\text { return }(\%)\end{array}$ & $\begin{array}{l}\text { Trading } \\
\text { volume }\end{array}$ & $\begin{array}{l}\text { Trading } \\
\text { value }\end{array}$ & $\begin{array}{l}\text { Turnover } \\
\text { Rate }(\%)\end{array}$ \\
\hline 1997 & 31.78 & $116,596,166$ & $1,354,875,522$ & 460.23 & -16.63 & $4,970,919$ & $21,292,850$ & 73.315 \\
\hline 1998 & -3.09 & $108,434,148$ & $1,230,286,511$ & 311.40 & -48.62 & $4,253,531$ & $8,888,373$ & 57.30 \\
\hline 1999 & 19.04 & $148,819,167$ & $1,682,612,596$ & 326.92 & 32.04 & $7,213,185$ & $13,959,198$ & 88.547 \\
\hline 2000 & 51.00 & $231,164,088$ & $3,092,785,647$ & 385.79 & 136.21 & $12,682,855$ & $34,304,480$ & 149.09 \\
\hline 2001 & -21.89 & $142,973,286$ & $1,987,720,445$ & 184.94 & 91.55 & $39,027,654$ & $283,261,804$ & 430.39 \\
\hline 2002 & -17.13 & $167,468,862$ & $1,644,170,832$ & 178.54 & -33.83 & $8,756,350$ & $51,738,448$ & 94.82 \\
\hline 2003 & 10.57 & $263,816,685$ & $2,057,226,251$ & 244.05 & -7.55 & $6,145,886$ & $28,799,222$ & 65.64 \\
\hline 2004 & -15.23 & $355,101,193$ & $2,623,001,429$ & 278.18 & -27.91 & $5,738,137$ & $25,803,763$ & 57.29 \\
\hline 2005 & -8.2136 & $392,689,321$ & $1,896,712,300$ & 268.925 & -18.03 & $5,969,482$ & $17,872,217$ & 57.67 \\
\hline
\end{tabular}

Note: Trading volume and market capitalization are expressed in thousand shares and RMB yuan, respectively.

Data source: Shanghai Stock Exchange.

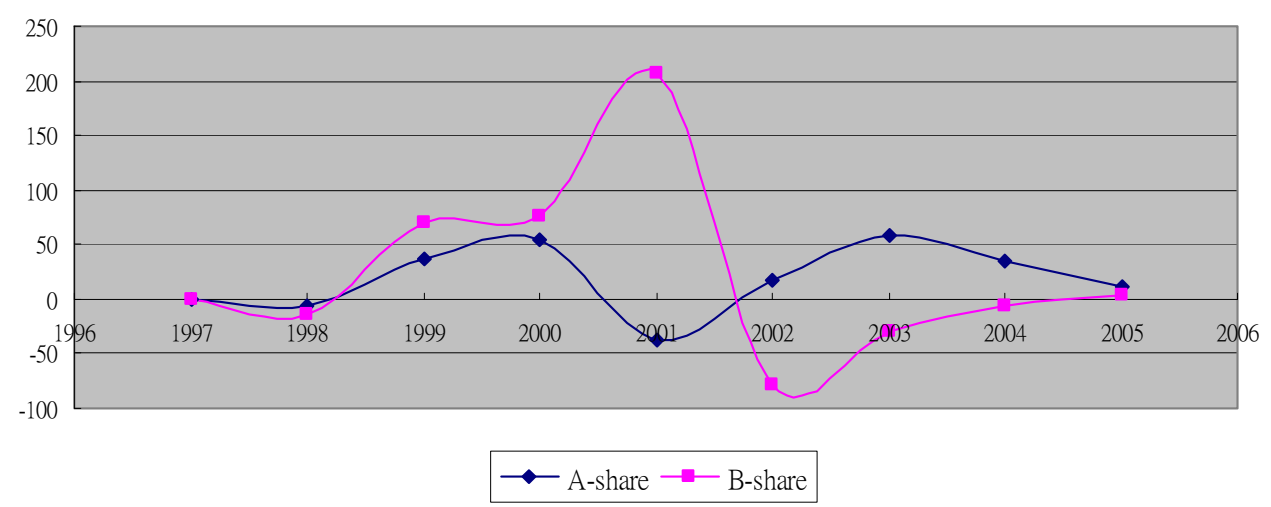

Figure 1. Trading volume growth rate (\%) of Shanghai A- and B-share markets

Unlike the trading activity in year 2001, the trading activity in the B-share market deviated from what would be expected due to the QFII initiative. Conversely, A-share market trading activity has obviously increased by as 
much as expected, which may curb the continuing growth of B-share market. Figure 1 shows a positive growth rate for A-shares and a negative growth rate for B-shares. Due to the changing phenomenon of both A- and B-share trading activity, inward and outward market liberalization implies an interesting story regarding the price behaviors between A- and B-share markets and effects of market information arrival on cross-market dynamic correlation.

To establish a basis for GARCH type models, it is necessary to present preliminary comparison of data attributes. Table 2 provides descriptive statistics for both the A- and B-share markets. The mean and kurtosis seem to be larger for A-share than B-share (adjusted B-shares) except for when the statistics of variance and skewness are smaller for A-shares than B-shares (adjusted B-shares). Furthermore, Table 3 shows that the asymmetric tests proposed by Engle and $\mathrm{Ng}$ (1993), along with the Engle ARCH test and it is evidenced that conditional variances of the rate of returns of A- and B-share markets are likely to be asymmetric as well as returns reflective of ARCH effect. These statistics provide the basis of using asymmetric GARCH type models to analyze the dynamic relationships between the A- and B-share stock markets of the Shanghai Securities Exchange.

Table 2. Descriptive statistics of returns

\begin{tabular}{llllllll}
\hline & Mean & Var. & Kurtosis & Skew & LB & LB $^{2}$ & JB test \\
\hline$R_{A, t}$ & 0.0112 & 2.3291 & $5.9933^{* *}$ & 0.0359 & $46.5412^{* *}$ & $319.5126^{* *}$ & $3246.7031^{* *}$ \\
$R_{B, t}$ & -0.0040 & 5.4694 & $3.5357^{* *}$ & $0.3217^{* *}$ & $59.4539^{* *}$ & $772.6160^{* *}$ & $1167.1866^{* *}$ \\
\hline
\end{tabular}

Notes: LB refers to the Ljung-Box statistic with returns for 24 lags, and $\mathrm{LB}^{2}$ refers to the Lung-Box statistic with squared returns for 24 lags. JB test is Jarque-Bera normality test. Var. stands for variance. * indicates significance at the $10 \%$ level. ** indicates significance at least at the $5 \%$ level.

Table 3. Asymmetric and LM test ( $t$ statistics and LM statistics)

\begin{tabular}{llllll}
\hline & SN & SNU & SPU & LM test & Engle test \\
\hline$R_{A, t}$ & 1.5268 & $-8.3816^{* *}$ & 1.5884 & $91.0591^{* *}$ & $7124.5504^{* *}$ \\
$R_{B, t}$ & -0.2844 & $-4.6685^{* *}$ & $6.1459^{* *}$ & $81.6304^{* *}$ & $261.6710^{* *}$ \\
\hline
\end{tabular}

Notes: *** Indicates significance at the $1 \%$ level. * indicates significance at the $10 \%$ level. ** indicates significance at least at the $5 \%$ level. The regression for Engle and $\mathrm{Ng}$ tests are as follows:

Sign bias test (SN): $z_{t}^{2}=a+b s_{t-1}^{-}+\mu_{t}$

Negative size bias test (SNU): $z_{t}^{2}=a+b s_{t-1}^{-} \varepsilon_{t}+\mu_{t}$

Positive size bias test (SPU): $z_{t}^{2}=a+b\left(1-s_{t-1}^{-}\right) \varepsilon_{t-1}+\mu_{t}$

Joint test (LM test): $z_{t}^{2}=a+b_{1} s_{t-1}^{-}+b_{2} s_{t-1}^{-} \varepsilon_{t-1}+b_{3}\left(1-s_{t-1}^{-}\right) \varepsilon_{t-1}+\mu_{t}$

where, $z_{t}^{2}$ is a standardized return squared, $\varepsilon_{t}$ is the demeaned return, and $s_{t}^{-}$is a dummy that takes the value of unity if $\varepsilon_{t}-1<0$ and zero otherwise.

\section{Empirical Results}

The empirical results of this study are shown in the following four subsections. The first subsection presents the results of the unit root and cointegration tests. Results of bivariate EGARCH model will be reported in the second subsection. The third subsection deals with the time-varying correlation and diagnostic statistics are in the fourth subsection.

\subsection{Results of Unit Root and Cointegration Tests}

The results of the unit root and cointegration tests are presented in Table 4 . They indicate that the null hypothesis of the unit root test cannot be rejected for $P_{A, t}$ under 'Break in Trend only' and that unit root is found for $P_{B, t}$. No cointegration is confirmed between A-share and B-share index price series and in spite of no long-term relationship, we may often expect the short-term dynamics between A- and B-share stockmarkets.

This study runs the bivariate EGARCH model without including the error correction term. Furthermore, based on the results of cointegration tests under different model types, the possible structural break dates fall on March 7, 12, and 20, 2001, respectively, which are near to February 28, 2001, the date when B-share stock market resumes trading. Notice that although these structural break dates do not directly correspond to the QFII event, the A-share market should still play a relatively major role in information transmission because market capitalization and trading volume of A-share still stays on the top of B-share. 
Table 4. Zivot and Andrew unit root and Gregory and Hansen cointegration test

\begin{tabular}{llll}
\hline Panel A & \multicolumn{2}{l}{ Unit Root (Zivot and Andrew) test statistics } & \\
Index price series & Break in Intercept Only & Break in Trend Only & Break in Both \\
\hline$P_{A, t}$ & $-5.5379^{* *}$ & -3.8732 & $-5.3012^{* *}$ \\
$P_{B, t}$ & -3.6919 & -2.0833 & -3.4594 \\
\hline Panel B & \multicolumn{2}{l}{ Gregory and Hansen Cointegration test statistics } & \\
Lag method: & T test ${ }^{a}$ & AIC $^{a}$ & BIC $^{a}$ \\
\hline Model type: Break in intercept, no trend & $-2.7542(1)$ & $-2.7124(3)$ & $-2.7542(1)$ \\
Model type: Break in intercept, trend included & $-4.2875(3)$ & $-4.2875(3)$ & $-4.3798(1)$ \\
Model type: Full structural Break & $-3.3025(3)$ & $-3.2943(3)$ & $-3.3025(1)$ \\
\hline
\end{tabular}

Notes: $P_{A, t}$ and $P_{B, t}$ represent the natural logarithm of index's prices of the Shanghai A-share, Shanghai B-share, respectively. The Zivot and Andrew's critical values for break in intercept only, break in trend only, and break in both are -4.80(-5.34), -4.42(-4.93), and -5.08(-5.57), at the $5 \%(1 \%)$ level, respectively. In addition, the lag method used is the $t$ test. ${ }^{a}$ indicates the method for deciding the number of additional lags and the corresponding statistics. The Gregory and Hansen's cointegration test involves the structural break and applies a traditional ADF test to the cointegrating residuals. The critical values of Gregory and Hansen (1996) are $-4.61(-5.13)$ at the $5 \%(1 \%)$ level for break in intercept with no trend, $-4.99(-5.45)$ at the $5 \%(1 \%)$ level for break in intercepted with trend, and $-4.95(-5.47)$ at the $5 \%(1 \%)$ level for full structural break. The number of lags of the change in the residual used to compute the ADF statistic appears in the parenthesis. In addition, the structural break dates are March 7, 12, and 20, 2001 under different model types. If the $t$-test is used to decide the number of additional lags, then the cutoff significance level, $10 \%$, is used. $* *$ Indicates significance at least at the $5 \%$ level.

CSRC prohibited investing in B-shares using foreign currency deposited into the required accounts during a short period from February 19 to May 31, 2001 to prevent excess market volatility immediately after the announcement. In spite of this prohibition, domestic investors engaging in B-share trading before June 1, 2001 were only allowed to use spot exchange deposits and foreign currency cash deposits deposited in domestic commercial banks before and including February 19. Thus, these structural break dates falling on between February 19 and May 31 should be reasonably and empirically accepted. Thus, this study reports the main empirical results using March 12, 2001 as a break date. The empirical results remain qualitatively unchanged when using other structural break dates.

\subsection{Results of the Bivariate EGARCH Model}

As Table 5 shows, the coefficients of MA (1) term are positive and statistically significant for the A- and B-share markets, suggesting some sort of infrequent trading or market friction. No mean spillover appears between Aand B-share markets before B-share's opening. However, the parameter $\gamma_{10}^{*}$ is negatively significant, representing a mean spillover from B- to A- share markets since opening B-share and not the other way around. Turning to the US exogenous effect, these results suggest that significant mean spillovers exist from the US stock market to only the B-share stock market in the whole period and in the post-opening period. Furthermore, the significance of both $\emptyset_{20}$ and $\emptyset_{20}^{*}$ suggests that B-share stock market returns were influenced only by the US stock market returns.

The parameters $\delta_{11}$ and $\delta_{21}$ represent the effects of market lagged standardized innovations on the conditional volatility for each market. With $w_{1}$ and $w_{2}$ being negative and statistically significant, both A- and B-share stock markets show leverage effect. In addition, Table 5 summarizes the asymmetric effect quantified by relative asymmetry for each stock market's returns. The quantity of the A-share market is larger than one, indicating larger negative asymmetry. The B-share market also shows negative asymmetry, but to a lesser extent.

The parameters $\delta_{12}$ and $\delta_{22}$ represent the effects of cross-market lagged standardized innovations on the conditional volatility for the A-share and B-share stock markets, respectively. Only the parameter $\delta_{22}$ is statistically significant, meaning that there exists unidirectional volatility spillover effect from A- to B-share stock markets, namely, adverse cross-market leverage effect, and not the other way around. However, such volatility spillover seems disappear in the post-opening period. $\theta_{21}^{*}$ is statistically significant but not for $\delta_{22}^{*}$, indicating that the B-share market is also influenced by the US market volatility, together with its own B-share market (Note 4). Thus, the US market seems to have played an important role of information transmission to the B-share market, especially for the post-opening period, while the A-share market volatility is mainly spilled over by its own volatility.

Empirical results also show that the degree of volatility persistence, as measured by $b_{i}(i=1,2)$, is significant and less than one (Table 5), which is a necessary condition for the unconditional variance to be finite. The A-share market exhibits strong persistence, while the B-share market exhibits weak persistence. This result is 
consistent with that of Kanas (1998), but differs from that of Corhay and Rad (1994). The quantity of half-life describes the degree of persistence. For example, it takes 6.9363 days for the shocks to reduce its effect by half for the Shanghai B-share stock market.

Table 5. Estimation results of the bivariate EGARCH model

\begin{tabular}{clllll}
\hline Parameters & \multicolumn{2}{c}{ Shanghai A-share } & \multicolumn{2}{c}{$\begin{array}{c}\text { Parameters } \\
\text { Mean equations }\end{array}$} & \multicolumn{2}{c}{$\begin{array}{c}\text { Shanghai B-share } \\
\text { coefficient }\end{array}$} \\
Mean equations & coefficient & t-statistic & $\mu_{2}$ & -0.1009 & $-47.3974^{* *}$ \\
\hline$\mu_{1}$ & -0.0473 & $-3.0396^{* *}$ & $\beta_{2}$ & 0.1180 & $31.9329^{* *}$ \\
$\beta_{1}$ & 0.0465 & $2.8988^{* *}$ & $\gamma_{20}$ & -0.0319 & -0.8373 \\
$\gamma_{10}$ & -0.0011 & 0.0129 & $\gamma_{20}^{*}$ & -0.0367 & -1.0632 \\
$\gamma_{10}^{*}$ & -0.0462 & $-2.7424^{* *}$ & $\emptyset_{20}$ & 0.2417 & $6.8845^{* *}$ \\
$\emptyset_{10}$ & 0.0496 & 1.7176 & $\emptyset_{20}^{*}$ & -0.2230 & $-6.3789^{* *}$ \\
$\emptyset_{10}^{*}$ & -0.0364 & -1.1905 & & & $11.5047^{* *}$ \\
$a_{1}$ & & & $a_{2}$ & 0.1467 & $110.0044^{* *}$ \\
$b_{1}$ & 0.0546 & $9.3340^{* *}$ & $b_{2}$ & 0.9049 & $11.5275^{* *}$ \\
$\delta_{11}$ & 0.9580 & $189.6798^{* *}$ & $\delta_{21}$ & 0.3691 & $-8.3258^{* *}$ \\
$\delta_{12}$ & 0.2261 & $13.2983^{* *}$ & $\delta_{22}$ & -0.1251 & 1.3543 \\
$\delta_{12}^{*}$ & -0.0051 & -0.1312 & $\delta_{22}^{*}$ & 0.0648 & $2.9515^{* *}$ \\
$\theta_{11}$ & 0.0222 & 0.5020 & $\theta_{21}$ & 0.0831 & $-4.5381^{* *}$ \\
$\theta_{11}^{*}$ & -0.0103 & -0.6731 & $\theta_{21}^{*}$ & -0.1196 & $-2.1884^{* *}$
\end{tabular}

Notes: The numbers in parentheses indicate $t$-statistics. The $t$-statistic was calculated using Bollerslev and Wooldridge's (1992) robust standard errors.* indicates significance at the $10 \%$ level. ${ }^{* *}$ indicates significance at least at the $5 \%$ level. The statistics of relative asymmetry are greater than, equal to, and less than one for negative asymmetry, symmetry, and positive asymmetry, respectively.

Table 6. Results of hypothesis testing

\begin{tabular}{clll}
\hline Hypothesis Tests: & Chi square statistics & P-values & Implication: \\
\hline $\mathrm{H}_{01}: \mathrm{b}_{1}=1$ & 69.0224 & $<0.01$ & $\begin{array}{l}\text { Indicates that degree of volatility persistence of A-share market is significant } \\
\text { and less than one. }\end{array}$ \\
$\mathrm{H}_{02}: \mathrm{b}_{2}=1$ & 133.6600 & $<0.01$ & $\begin{array}{l}\text { Indicates that degree of volatility persistence of B-share market is significant } \\
\text { and less than one. }\end{array}$ \\
$\mathrm{H}_{03}:\left|\theta_{11}^{*}\right|=\left|\theta_{21}^{*}\right|$ & 11.8194 & $<0.01$ & $\begin{array}{l}\text { Indicates that the US market volatility influences B-share market more than } \\
\text { A-share market. }\end{array}$ \\
$\mathrm{H}_{04}:\left|\mathrm{c}_{3}^{*}\right|=\left|\mathrm{c}_{4}^{*}\right|$ & 0.4371 & 0.5085 & Both information arrivals have equal effect on cross-correlation.
\end{tabular}

\subsection{Time-Varying Correlations}

This subsection analyzes the conditional correlations between the Shanghai A- and B-share stock markets. Tables 5 and 6, along with Figure 2, present the empirical estimates of correlation index function, descriptive statistics of correlations and the graph of time-varying correlation coefficients, respectively. Note that both A- and B-share market returns are highly correlated, on average, with a value of 0.6313 for the period of this study. The values of cross-correlation coefficients oscillate between a maximum of 0.9518 and a minimum of 0.0881 , indicating that the coefficients are restricted between zero and positive one. The result of ADF unit root test (though not reported here) indicates the stationarity of conditional correlations. With respect to behavior of correlation, we can find out from observing Figure 2 that one of the periods of obviously increasing correlation falls on year 2001 when the policy of opening B-share to trade started to take effect. In addition, Figure 2 reveals a generally upward trend in cross-market correlation, which indicates an overall increasing correlation. The increasing 
correlation could be warranted by observing the change in mean values of correlation from 0.4682 for the period before structural break date to 0.7715 for post-opening period.

Table 7. Descriptive statistics of cross-correlations

\begin{tabular}{lllllll}
\hline$\rho_{12, t}$ & Mean & Var. & Excess Kurtosis & Skew & Maximum & Minimum \\
\cline { 2 - 7 } & $0.6313^{* * *}$ & 0.0473 & $-0.3985^{* *}$ & $-0.8675^{* *}$ & 0.9518 & 0.0881 \\
\hline
\end{tabular}

Note: Jarque-Bera normality test. Var. stands for variance. Var. stands for variance. $* *$ indicates significance at least at the $5 \%$ level.

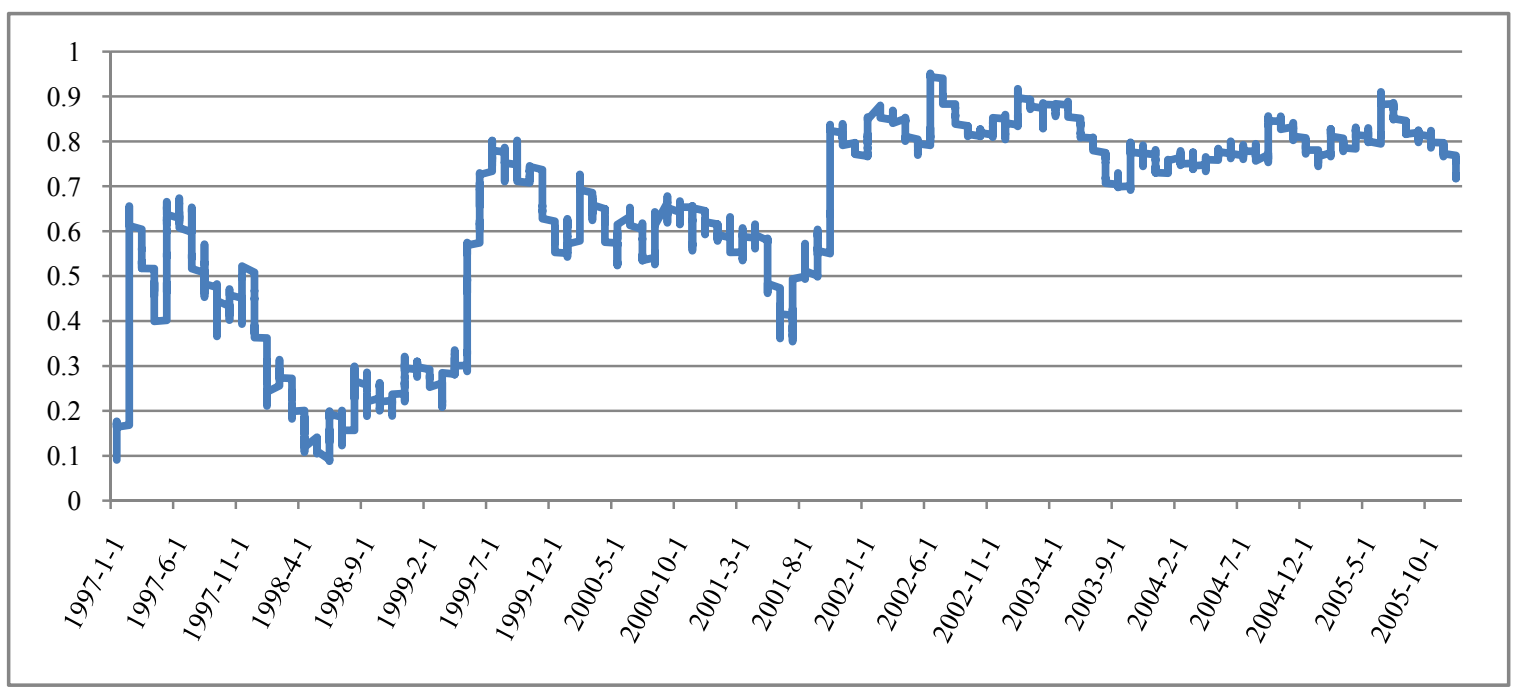

Figure 2. Time-varying correlation between the Shanghai A- and B-share stock market return

Regarding the index function (Equation (15)), it shows that the $\mathrm{ARCH}$ parameter $C_{1}$ is small, positive, and significant and that the GARCH parameter $C_{2}$ is large and close to one, showing a high degree of persistence in conditional correlations. These findings are similar to those of Darbar and Deb (2002) and Skintzi and Refenes (2006).

Closer examination of the coefficients of market information arrival shows that both A- and B-share markets play important information roles leading to interactions with different signs. Signs have been reversed for the post-opening period but with equivalent impact on cross-market correlation, as Table 5 shows. The A-share market's information arrivals increase subsequent correlation, while the B-share market's information arrivals reduce subsequent correlation in the post-opening period. One explanation of increasing correlation is that an increase in the volatility of the common factor associated with information that affects both A- and B-share markets in the same direction, while an increase in the volatility of the common factor affecting both A- and B-share markets in opposite directions will decrease the subsequent correlation. The other explanation is that an increase in volatility of market-specific factor will decrease the subsequent correlation. What is more important is that the magnitudes of information arrival coefficient with absolute values $\left|C_{3}^{*}\right|$ and $\left|C_{4}^{*}\right|$ increase in the post-opening period, which may testify to the effectiveness of opening the B-shares: an increasing responsiveness of cross-market correlation to information arrival.

\subsection{Diagnostic Tests}

Table 8 presents the diagnostic statistics of this study. Ljung-Box $Q(24)$ and $Q^{2}(24)$ tests applied to the standardized residuals and squared standardized residuals indicate that the estimated bivariate EGARCH model is correctly specified. Results of the Engle and $\mathrm{Ng}$ test, as a complementary test to Ljung-Box test, indicate a reasonable fit of the estimated bivariate EGARCH model to the data considered. Furthermore, the joint null hypothesis that the mean and variance of standardized residuals are zero and unity respectively is not rejected. To sum, these types of diagnostic statistics confirm that the bivariate EGARCH model is well and adequately specified. 
Table 8. Results of diagnostic tests

\begin{tabular}{lll}
\hline & Shanghai A & Shanghai B \\
\hline$P$ values for Ljung-Box $Q(24)$ statistics: & & 0.4923 \\
$\mathrm{z}$ & 0.2426 & 0.7452 \\
$\mathrm{z}^{2}$ & 0.8855 & \\
$\mathrm{z}_{1} \mathrm{z}_{2}$ & 0.4682 & $<0.001$ \\
$P$ values for Skewness of $\mathrm{z}$ & 0.0846 & $<0.001$ \\
$P$ values for excess Kurtosis of $\mathrm{z}$ & $<0.001$ & \\
$P$ values for Engle and Ng $(1993)$ diagnostic Tests: & & 0.3506 \\
Sign bias test & 0.7421 & 0.6565 \\
Negative size bias test & 0.1712 & 0.9233 \\
Positive size bias test & 0.9873 & 0.7729 \\
Joint test $(F$-statistics $)$ & 0.5251 & \\
Mean and variance of the standardized residuals & & 0.0222 \\
$E\left(\varepsilon_{\mathrm{t}} / \sigma_{\mathrm{t}}\right)$ & 0.0193 & 0.9937 \\
$E\left[\left(\varepsilon_{t} / \sigma_{t}\right)^{2}\right]$ & 0.9886 & $0.5864(P$-value $=0.5564)$ \\
Null hypothesis: mean=0 and variance $=1(F$-test statistics $)$ & $04290(P$-value $=0.6512)$ \\
Joint null hypothesis: mean=0 and variance $=1$ for both markets $(F$-test $0.3238(P$-value $=0.8622)$ & \\
statistics $)$ & & \\
\hline
\end{tabular}

Notes: $z$ and $z^{2}$ refer to the standardized residual and the squared standardized residual for the corresponding equations, respectively, and $\mathrm{z}_{1} \mathrm{z}_{2}$ is the cross product of the two standardized residuals.

\section{Summary and Conclusions}

This study uses a bivariate EGARCH model to examine the changing nature of spillovers and dynamic conditional correlations using data from the Shanghai A- and B-share markets as well as the US markets for the period January 2, 1997 to December 30, 2005. The opening of the B-share market to Chinese citizens was the motivation for this empirical investigation on dynamic relationship between the A- and B-share stock markets.

The results of this study reveal that the proposed bivariate EGARCH model with MA(1) can accurately describe both Shanghai A- and B-share market returns. Both Ljung-Box tests and Engle and Ng tests indicate that the estimated models are well specified. The Zivot and Andrews (1992) unit root test shows that the index prices of the A-share are non-stationary or stationary. In spite of a major structural event (e.g., B-share's opening that is detected by the method of Gregory and Hansen), the cointegration between A- and B-share stock markets is not found. A mean spillover from the B- to A-share market was found and not the other way around in the post-opening period; for the same period, volatility spillover from the US stock market to the B-share market was also detected, partly implying international information used by traders in the B-share market.

The regression results of time-varying correlation model, attached to the EGARCH model, indicate that both Aand B-share stock markets play a role of information arrival in terms of transmission to conditional correlation, and that this information role has increased since the opening of the B-share market. That is to say, an increase in responsiveness of cross-market correlation to information arrival has been observed after B-share's opening to Chinese citizens. Finding of spillovers and responsiveness of correlation to information arrivals suggests that portfolio managers may have to rebalance their asset allocation for investment performance.

\section{References}

Bae, K. H., \& Karolyi, G. A. (1994). Good news, bad news and international spillovers of stock return volatility between Japan and the US. Pacific-Basin Finance, 2, 405-438. http://dx.doi.org/10.1016/0927-538X(94)90003-5

Bekaert, G., \& Harvey, C. R. (2000). Foreign speculators and emerging equity markets. Journal of Finance, 55, 566-613. http://dx.doi.org/10.1111/0022-1082.00220

Bekaert, G., Harvey, C. R., \& Ng, A. (2005). Market integration and contagion. Journal of Business, 78, 38-70. http://dx.doi.org/10.1086/426519

Bhar, R. (2001). Return and volatility dynamics in the spot and futures markets in Australia: an intervention analysis in a bivariate EGARCH-X framework. The Journal of Futures Markets, 21, 833-850. http://dx.doi.org/10.1002/fut.1903

Black, F. (1976). Studies of stock market volatility changes. Proceedings of the American Statistical Association, 
Business and Economics Studies Section, 177-181.

Bollerslev, T. (1987). A conditionally heteroscedastic time series model for speculative prices and rates of return. Review of Economics Statistics, 69, 542-547. http://dx.doi.org/10.2307/1925546

Bollerslev, T., \& Wooldridge, J. (1992). Quasi-Maximum likelihood estimation and inference in dynamic models with time-varying covariances. Econometric Review, 11, 143-172. http://dx.doi.org/10.1080/07474939208800229

Bollerslev, T., Engle, R., \& Nelson, D. (1994). ARCH Models. In Engle, R., \& McFadden, D. (Eds.), Handbook of Econometrics (vol. 4, pp. 2960-3038). New York: Elsevier Science.

Booth, G. G., Martikainen, T., \& Tse, Y. (1997). Price and volatilities spillovers in Scandinavian stock markets. Journal of Banking and Finance, 21, 811-823. http://dx.doi.org/10.1016/S0378-4266(97)00006-X

Cajueiro, D. O., Gogas, P., \& Tabak, B. M. (2009). Does financial market liberalization increase the degree of market efficiency? The case of the Athens stock exchange. International Review of Financial Analysis, 18, 50-57. http://dx.doi.org/10.1016/j.irfa.2008.11.004

Chan, K. C., Fung, H. G., \& Thapa, S. (2007). China financial research: A review and synthesis. International Review of Economics and Finance, 16, 416-428. http://dx.doi.org/10.1016/j.iref.2005.09.004

Christie, A. A. (1982). The stochastic behavior of common stock variances: value, leverage, and interest rate effects. Journal of Financial Economics, 10, 407-432. http://dx.doi.org/10.1016/0304-405X(82)90018-6

Corhay, A., \& Rad, A. T. (1994). Daily returns from European stock markets. Journal of Business Finance and Accounting, 21, 271-281. http://dx.doi.org/10.1111/j.1468-5957.1994.tb00318.x

Covrig, V., \& Ng, L. (2004). Volume autocorrelation, information, investor trading. Journal of Banking and Finance, 28, 2155-2174. http://dx.doi.org/10.1016/j.jbankfin.2003.08.005

Darbar, S. M., \& Deb, P. (2002). Cross-market correlations and transmission of information. Journal of Futures Markets, 22, 1059-1082. http://dx.doi.org/10.1002/fut.10045

Domanski, D., \& Kremer, M. (2000). The dynamics of international asset price linkages and their effects on German stock and bond markets. In BIS conference papers: International Financial Markets and Financial Stability, BIS, Basel, Switzerland, 134-158.

Engle, R. F., \& Kroner, K. F. (1995). Multivariate simultaneous generalized ARCH. Econometric Review, 11, $122-150$.

Engle, R. F., \& Ng, V. K. (1993). Measuring and testing the impact of news on volatility. Journal of Finance, 48, 1749-1778. http://dx.doi.org/10.1111/j.1540-6261.1993.tb05127.x

Eun, C. S., \& Shim, S. (1989). International transmission of stock market movements. Journal of Financial and Quantitative Analysis, 24, 41-56. http://dx.doi.org/10.2307/2330774

Glosten, L. R., Jagannathan, R., \& Runkle, D. (1993). On the relation between the expected value and the volatility of the nominal excess return on stocks. Journal of Finance, 48, 1779-1801. http://dx.doi.org/10.1111/j.1540-6261.1993.tb05128.x

Gregory, A., \& Hansen, B. E. (1996). Residual-based tests for cointegration in models with regime shifts. Journal of Econometrics, 70, 99-126. http://dx.doi.org/10.1016/0304-4076(69)41685-7

Gulen, H., \& Mayhew, S. (2000). Stock index futures trading and volatility in international equity markets. $\begin{array}{lllll}\text { Journal } \quad \text { Futures } & \text { markets, }\end{array}$ http://dx.doi.org/10.1002/1096-9934(200008)20:7<661::AID-FUT3>3.0.CO;2-R

Gupta, R., \& Donleavy, G. D. (2009). Benefits of diversifying investments into emerging markets with time-varying correlations: an Australian perspective. Journal of Multinational Financial Management, 19, 160-177. http://dx.doi.org/10.1016/j.mulfin.2008.10.001

Gupta, R., \& Mollik, A. T. (2008). Volatilities, time-varying correlation and international portfolio diversification: en empirical study of Australia and emerging markets. International Research Journal of Finance and Economics, 18, 18-37.

Hamao, Y. R., Masulis, R. W., \& Ng, V. K. (1990). Correlation in price changes and volatility across international stock markets. Review of Financial Studies, 3, 281-307. http://dx.doi.org/10.1093/rfs/3.2.281

Hansen, L. P. (1982). Large sample properties of generalized method of moments estimators. Econometrica, 50, 
1029-1054. http://dx.doi.org/10.2307/1912775

Hausman, J. A. (1978). Specification test in econometrics. Econometrica, 46, 1251-1271. http://dx.doi.org/10.2307/1913827

Hung, J. C. (2009). Deregulation and liberalization of the Chinese stock market and the improvement of market efficiency. Quarterly Review of Economics and Finance, 49, 843-857. http://dx.doi.org/10.1016/j.qref.2009.04.005

Jaleel, F. M., \& Samarakoonb, L. P. (2009). Stock market liberalization and return volatility: Evidence from the emerging market of Sri Lanka. Journal of Multinational Financial Management, 19, 409-423. http://dx.doi.org/10.1016/j.mulfin.2009.07.006

Jayasuriya, S. (2005). Stock market liberalization and volatility in the presence of favorable market characteristics and institutions. Emerging Markets Review, 6, 170-191. http://dx.doi.org/10.1016/j.ememar.2005.03.001

Jeon, B., \& Chiang, T. (1991). A system of stock prices in World stock exchange: common stochastic trends for 1975-1990? Journal of Economic and Business, 43, 329-338. http://dx.doi.org/10.1016/0148-6195(91)90029-V

Jochum, C. (2001). Is the covariance of international stock market returns regime dependent? European Journal of Finance, 7, 247-268. http://dx.doi.org/10.1080/13518470010042210

Kanas, A. (1998). Volatility spillovers across equity markets: European evidence. Applied Financial Economics, 8, 245-256. http://dx.doi.org/10.1080/096031098333005

Karolyi, G. A. (1995). A multivariate GARCH model of international transmissions of stock returns and volatility: the case of the United States and Canada. Journal of Business and Economic Statistics, 13, 11-25.

Karolyi, G. A., \& Stulz, R. M. (1996). Why do markets move together? An investigation of US-Japan stock return co-movements. Journal of Finance, 51, http://dx.doi.org/10.1111/j.1540-6261.1996.tb02713.x

King, M., Sentana, E., \& Wadhwani, S. (1994). Volatility and links between national stock markets. Econometrica, 62, 901-933. http://dx.doi.org/10.2307/2951737

Koch, P. D., \& Koch, T. W. (1991). Evolutions in dynamic linkages across national stock indexes. Journal of International Money and Finance, 10, 231-251. http://dx.doi.org/10.1016/0261-5606(91)90037-K

Koutmos, G., \& Booth, G. G. (1995). Asymmetric volatility transmission in international stock markets. Journal of International Money and Finance, 14, 747-762. http://dx.doi.org/10.1016/0261-5606(95)00031-3

Lamoureux, C. G., \& Lastrapes, W. D. (1990). Heteroscedasticity in stock return data: Volume vs. GARCH effects. Journal of Finance, 45, 221-229. http://dx.doi.org/10.1111/j.1540-6261.1990.tb05088.x

Lin, Y. A., \& Swanson, P. E. (2008). The Effect of China's Reform Policies on Stock Market Information Transmission. Quarterly Journal of Finance and Accounting, 47, $49-75$.

Longin, F., \& Solink, B. (1995). Is the correlation in international equity returns constant: 1960-1990. Journal of International Money and Finance, 14, 3-26. http://dx.doi.org/10.1016/0261-5606(94)00001-H

Lu, C., Wang, K., Chen, H., \& Chong, J. (2007). Integration A- and B-share markets in China: the effects of regulatory policy changes on market efficiency. Review of Pacific Basin Financial Markets and Policies, 10, 309-323. http://dx.doi.org/10.1142/S0219091507001082

McAleer, M. (2005). Automated inference and learning in modeling financial volatility. Econometric Theory, 21, 232-261. http://dx.doi.org/10.1017/S0266466605050140

Morrison, D. (1983). Applied linear statistical methods. New Jersey: Prentice Hall, Inc.

Muthuswamy, J., Sarkar, S., Low, A., \& Terry, E. (2001). Time variation in the correlation structure of exchange rates: High frequency analysis. Journal of Futures markets, 21, 127-144. http://dx.doi.org/10.1002/1096-9934(200102)21:2<127::AID-FUT2>3.0.CO;2-B

Narayan, P., \& Smyth, R. (2005). Cointegration of stock markets between New Zealand, Australia and G7 economies: searching for comovement under structural change. Australian Economic Papers, 44, 231-247. http://dx.doi.org/10.1111/j.1467-8454.2005.00262.x

Nelson, D. (1991). Conditional heteroscedasticity in asset returns: A new approach. Econometrica, 59, 347-370. 
http://dx.doi.org/10.2307/2938260

Phillips, P. C. B., \& Perron, P. (1988). Testing for a Unit Root in Time Series Regression. Biometrika, 75, 335-346. http://dx.doi.org/10.1093/biomet/75.2.335

Qiao, Z., Chiang, T. C., \& Wong, W. K. (2008). Long-run equilibrium, short-term adjustment and spillover effects across Chinese segmented stock markets and Hong Kong stock market. Journal of International Financial Markets, Institutions and Money, 18, 425-437. http://dx.doi.org/10.1016/j.intfin.2007.05.004

Ramchand, L., \& Susmel, R. (1998). Volatility and Cross Correlation in Global Equity Markets. Journal of Empirical Finance, 5, 397-416. http://dx.doi.org/10.1016/S0927-5398(98)00003-6

Roll, R. (1989). Price volatility, international market links, and their implications for regulatory policies. Journal of Financial Services Research, 3, 211-246. http://dx.doi.org/10.1007/BF00122803

Ross, S. A. (1989). Information and volatility: the no-arbitrage martingale to timing and resolution irrelevance. Journal of Finance, 44, 1-47. http://dx.doi.org/10.1111/j.1540-6261.1989.tb02401.x

Scholes, M., \& Williams, J. T. (1977). Estimating betas from nonsynchronous data. Journal of Financial Economics, 5, 309-327. http://dx.doi.org/10.1016/0304-405X(77)90041-1

Shwert, G. W., \& Pagan, A. R. (1990). Alternative models for conditional stock volatility. Journal of Econometrics, 45, 267-290. http://dx.doi.org/10.1016/0304-4076(90)90101-X

Skintzi, V. D., \& Refenes, A. N. (2006). Volatility spillovers and dynamic correlation in European bond markets. Journal of International Financial Markets, Institutions and Money, 16, 23-40. http://dx.doi.org/10.1016/j.intfin.2004.12.003

Sun, Q., Tong, W. H. S., \& Yan, Y. (2009). Market liberalization within a country. Journal of Empirical Finance, 16, 18-41. http://dx.doi.org/10.1016/j.jempfin.2008.07.003

Susmel, R., \& Engle, R. F. (1994). Hourly volatility spillovers between international equity markets. Journal of International Money and Finance, 13, 3-25. http://dx.doi.org/10.1016/0261-5606(94)90021-3

Theodossiou, P., \& Lee, U. (1993). Mean and volatility spillovers across major national stock markets: further empirical evidence. Journal of Financial Research, 16, 337-350

Tse, Y. (1998). International transmission of information: evidence from the Euroyen and Eurodollar futures markets. Journal of International Money and Finance, 17, 909-929. http://dx.doi.org/10.1016/S0261-5606(98)00034-5

Wang, Y., \& Iorio, A. D. (2007). Are the China-related stock markets segmented with both World and regional markets? Journal of International Financial Markets, Institutions and Money, 17, 277-290. http://dx.doi.org/10.1016/j.intfin.2005.12.001

Zivot, E., \& Andrews, D. W. K. (1992). Further evidence on the great crash, the oil-price shock and the unit-root hypothesis. Journal of Business and Economic Statistics, 10, 251-270.

\section{Notes}

Note 1. An alternative model that also captures the leverage effect is the GJR GARCH model. However, the EGARCH model outperforms the GJR model in terms of function value.

Note 2. The inclusion of a first-order moving average could overcome the first-order autocorrelation problems caused by nonsynchronous data (Scholes and Williams, 1977), especially for this emerging market's data.

Note 3. Darbar and Deb (2002) presented a framework that formally clarified the relationship between returns and volatility and proposed a multivariate Logistic Exponential GARCH (LEGARCH) model, which makes testing hypotheses on the conditional more convenient.

Note 4 . Note that the parameter $\theta_{11}^{*}$ is marginally significant at the $10 \%$ level, meaning a little spillover effect from the US market to the A-share market. 